\title{
INTRODUCTION
}

\section{THE WASHINGTON DECLARATION ON INTELLECTUAL PROPERTY AND THE PUBLIC INTEREST}

\author{
SEAN M. FLYNN*
}

INTRODUCTION 1

I. CONVENING A GLOBAL NETWORK …....................................2

II. THE GLOBAL CONGRESS ON INTELLECTUAL PROPERTY AND THE PUBLIC INTEREST

\section{INTRODUCTION}

The last weekend in August 2011, between a freak earthquake and the arrival of Hurricane Irene, nearly 200 international intellectual property scholars and policy advocates gathered in Washington, D.C., to "re-articulate the public interest dimension in intellectual property law and policy." Global Congress on Intellectual Property and the Public Interest”produced the Washington Declaration on Intellectual Property and the Public Interest. The text of the Washington Declaration follows this introduction. The following pages provide a brief overview of the genesis of the network that was assembled at the Congress and of the process used to create its Declaration.

* American University Washington College of Law; Associate Director, Program on Information Justice and Intellectual Property ("PIJIP”).

1. Global Cong. On Intell. Prop. \& the Pub. Interest, Washington Declaration on Intellectual Property and the Public Interest (2011) [hereinafter Washington Declaration], available at http://infojustice.org/washingtondeclaration. 


\section{CONVENING A GLOBAL NETWORK}

The Global Congress and the Washington Declaration it created were an effort to renew a community and rearticulate an agenda that had been under construction since the early 1990s. ${ }^{2}$ In this effort, the Congress planners relied on and took inspiration from a series of influential convenings of scholars and advocates that created strands of a global network and defined its aspirations. The Congress was also influenced by the success and instruments of an industry-led "enforcement agenda" that was drawing increasing attention and resources from the public interest community.

One early convening that inspired the Congress was the 1993 meeting on "Cultural Agency/Cultural Authority: Politics and Poetics of Intellectual Property in the Post-Colonial Era,” sponsored by the Rockefeller Foundation. ${ }^{3}$ That meeting mapped a scholarly critique of "authorship" in legal and cultural discourse and produced the "Bellagio Declaration" to chart a path "forward to the future" and

2. Although international intellectual property law itself can be traced back to at least the 1880s, and rights-holder mobilizations to influence that corpus of law date back to the same period, the rise of a public interest civil society network on international intellectual property issues dates mainly to the 1990s in the run-up to and immediate aftermath of the World Trade Organization's Agreement on Trade Related Aspects of Intellectual Property Rights (TRIPS). The first major assertion of a public interest voice in the field distinct from and in tension with intellectual property holders' interests may be traced back to what has been called the first "development agenda," which arose in the international negotiations to amend the Paris and Berne Conventions and create the World Intellectual Property Organization in 1967. That agenda was led by developing countries, many newly independent, and led to a set of amendments to the Paris and Berne Conventions to promote technology transfer and the translation of works in local languages. But that agenda is not normally associated with a rise of a public interest voice in civil society of the kind that arose in the 1990s. See Peter Yu, A Tale of Two Development Agendas, 35 OHIO N.U. L. REV. 465 (2009).

3. See Patrick J. O’Keefe, Cultural Agency/Cultural Authority: Politics and Poetics of Intellectual Property in the Post-Colonial Era, 4 INT'L J. CULTURAL PROP. 388 (1995) (conference report of the meeting). The meeting was organized and chaired by Peter Jaszi of American University Washington College of Law and Martha Woodmansee of Case Western Reserve University, longtime collaborators on the co-evolution of the concept of "authorship" in legal and literary discourse. The meeting followed the publication of Peter Jaszi and Marthe Woodmansee's edited volume, THE CONSTRUCTION OF AUTHORSHIP, published by Duke University Press in 1992. 
better "recognize the public interest in access to information."4

The Bellagio Declaration sounded many themes that became recurrent in the public interest community in the coming decades. These included proclamations that intellectual property law has "profound effects" on broad segments of society, that the structure and assumptions of intellectual property tend to undervalue many important public interest concerns, that there is a need for increased attention to doctrines that protect the public domain and the interests of users and developing countries, and a call for "democratization of the fora in which the international intellectual property regime is debated and decided."5

4. O’Keefe, supra note 3, at 388.

5. The Bellagio Declaration, SOCIETY FOR CRITICAL EXCHANGE (1993), available at http://www.cwru.edu/affil/sce/BellagioDec.html. In most relevant part, the Declaration admonished:

First, Intellectual property laws have profound effects on issues as disparate as scientific and artistic progress, biodiversity, access to information, and the cultures of indigenous and tribal peoples. ... .

Second, Many of these problems are built into the basic structure and assumptions of intellectual property....

Third, a system based on such premises has real negative consequences. Increasingly, traditional knowledge, folklore, genetic material and native medical knowledge flow out of their countries of origin unprotected by intellectual property, while works from developed countries flow in, well protected by international intellectual property agreements, backed by the threat of trade sanctions.

Fourth, In general, systems built around the author paradigm tend to obscure or undervalue the importance of "the public domain," the intellectual and cultural commons from which future works will be constructed. ...

Fifth, we deplore these tendencies, deplore them as not merely unjust but unwise, and entreat the international community to reconsider the assumptions on which and the procedures by which the international intellectual property regime is shaped.

In general, we favor increased recognition and protection of the public domain. We call on the international community to expand the public domain through expansive application of concepts of "fair use," compulsory licensing, and narrower initial coverage of property rights in the first place. ...

Specifically, we advocate consideration of special regimes, possibly in the form of "neighboring" or "related" rights regimes, for the following areas:

- Protection of folkloric works.

- Protection of works of cultural heritage.

- Protection of the biological and ecological "know-how" of traditional peoples.

In addition, we support systematic reconsideration of the basis on which new kinds of works related to digital technology, such as computer programs and electronic data bases, are protected under national and international intellectual property regimes. ... 
Another set of convenings that were instrumental in creating the network of public interest advocates that the Congress sought to remobilize occurred through the "Bellagio Dialogues" sponsored by the Rockefeller Foundation from 2002 to 2006. ${ }^{6}$ These dialogues followed a decade of increased activism in the field, including mobilizations against patents on seeds and genetic resources (from 1993), ${ }^{7}$ opposition to a U.S. "Digital Agenda" for international copyright expansion (from 1995), ${ }^{8}$ and promotion of affordable access to patented medicines needed to treat AIDS (from 1999). ${ }^{9}$ The Bellagio Dialogues sought to support and connect a growing global network through a series of multiday workshops at a residential retreat near Geneva, connected to a five-year funding project to promote "fairness" in international intellectual property policy. ${ }^{10}$ The

On a systemic level, we call upon states and non-governmental organizations to move towards democratization of the fora in which the international intellectual property regime is debated and decided.

In conclusion, we declare that in an era in which information is among the most precious of all resources, intellectual property rights cannot be framed by the few to be applied to the many.

6. See Joe Karaganis, The Bellagio Global Dialogues on Intellectual Property, Am. Univ. Wash. Coll. of Program on Info. Justice \& INTEll. ProP. (PIJIP Working Paper Ser. No. 35, Dec. 2012), available at http://digitalcommons.wcl.american.edu/research/35/.

7. See Amy Kapczynski, The Access to Knowledge Mobilization and the New Politics of Intellectual Property, 117 YALE L.J. 804, at 825-26 (2008).

8. See Pamela Samuelson, WIPO Panel Principal Paper: The U.S. Digital Agenda at WIPO, 37 VA. J. INT’L L. 369 (1997).

9. Ellen 't Hoen, TRIPS, Pharmaceutical Patents, and Access to Essential Medicines: A Long Way from Seattle to Doha, 3 CHI. J. INT’L L. 27 (2002).

10. See Karaganis, supra note 6, at 6 . As described by Karaganis:

Fairness, in this context, meant balancing four general objectives:

- Reasonable returns on investment in research and development.

- $\quad$ Access to key research technologies and end products (such as medicines).

- Investment in research and development in areas with low commercial prospects.

- Protection of knowledge and materials created outside the commodity economy (such as traditional knowledge).

Substantively, it implied grantmaking in three general areas:

- Advancing the IP debate through policy analysis, policy development, and attention to process and representation in national and global policy settings.

- $\quad$ Strengthening institutional capacities, leadership, and coordination among pro-development actors in the IP field, with an emphasis on developing countries.

- Exploring and supporting alternative policy frameworks, models of 
series of meetings convened more than 200 advocacy leaders and scholars interested in a broad range of issues related to five main "threads": global trade and development policy, health, access to plant genetic resources, IP issues facing indigenous peoples, and alternative systems for innovation. ${ }^{11}$

A primary goal and outcome of the Bellagio Dialogues was to serve as a "focal point for a larger community of actors" working across the threads covered at the meetings. ${ }^{12}$ Workshops built connections primarily by inviting actors from different threads into a dialogue on "a particular policy goal (see the following figure ${ }^{13}$ ).

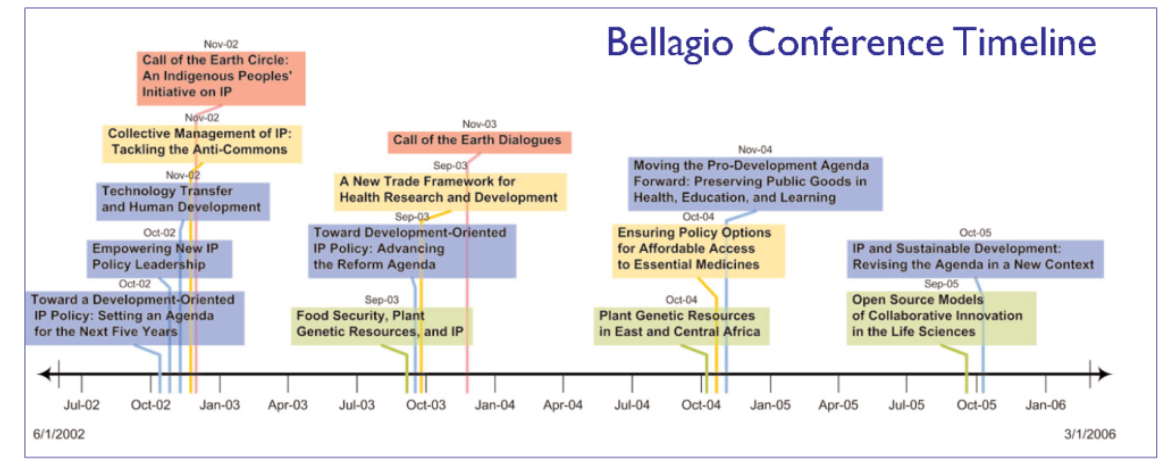

Unlike the 1993 Bellagio meeting, the Dialogues were not focused on producing public statements or deliverables at the meetings themselves. The outcomes were more organic and indirect-often through "wider network activities" including preparatory and followup meetings and workshops. ${ }^{14}$ With respect to the "DevelopmentOriented IP Policy" discussions, for example, an ongoing series of Bellagio Dialogues incubated a policy agenda that was ultimately adopted by the World Intellectual Property Organization. ${ }^{15}$ Momentum for the project and outlines of many of its key priorities can be traced

11. Id. innovation, and practices of IP management.

12. Id. at 8.

13. The figure is reprinted with permission from Karaganis, supra note 6, at 8 .

14. Id.

15. See generally Jeremy de Beer, Defining WIPO's Development Agenda, in IMPLEMENTING THE WORLD INTELLECTUAL PROPERTY ORGANIZATION'S DEVELopment AGENDA 3-6 (Jeremy de Beer ed., 2009) (reviewing the official history of the development agenda in WIPO from formal proposals dating from 1958 through WIPO sessions on the topic from 2004 to 2007). 
back to Bellagio Dialogue discussions beginning in 2002. But key meetings developing and promoting more specific platformsincluding a pivotal meeting in 2004 creating the Geneva Declaration on the Future of WIPO_-occurred elsewhere. ${ }^{16}$ The lasting impact of the Dialogues was as a point of intersection between different strands of a movement and a key funder supporting them, fostering "an increasingly coordinated and well resourced 'pro-development' global IP Policy community."17

The development of the Global Congress was also influenced by the means and ends of a counter-mobilization of intellectual property-intensive industries to broaden the scope and reach of intellectual property rights through complex strategies of forum (or "regime") shifting. ${ }^{18}$ At a time when a number of leading

16. See Agenda for a meeting in Lisbon on The WIPO Work Program (Oct. 17, 2003), http://www.cptech.org/ip/wipo/wipo10172003.html; Geneva Declaration on the Future of the World Intellectual Property Organization, http://www.cptech.org/ip/wipo/futureofwipodeclaration.html (last visited Nov. 28, 2012). Scholarship of the period that influenced the Geneva Declaration as well as the broader Development Agenda discussions included James Boyle, A Manifesto on WIPO and the Future of Intellectual Property, 2004 DuKE L. \& TECH. REV. 1; Keith E. Maskus \& Jerome H. Reichman, The Globalization of Private Knowledge Goods and the Privatization of Global Public Goods, 7 J. INT'L ECON. L. 279 (2004); Sisule Musungu \& Graham Dutfield, Multilateral Agreements and a TRIPS-Plus World: The World Intellectual Property Organisation (WIPO), QUAKER UNITED NATIONS OFFICE (2003), available at http://www.geneva.quno.info/pdf/WIPO\%28A4\%29final0304.pdf.

17. Karaganis, supra note 6 , at 8 ; see id. at 12-13, 21 (listing policy reform campaigns incubated at the Bellagio Dialogues, including proposals influencing the 2003 WTO decision on the implementation of paragraph 6 of the Doha Declaration on the TRIPS Agreement and public health; 2003 proposal for a Research and Development Treaty; 2005 proposed amendment to TRIPS on disclosure of genetic materials; 2005 draft of an Access to Knowledge Treaty; CAMBIA's BiOS initiative on open-source research in science; work by the World Health Organization, and ultimately UNITAID, to create a medicines patent pool; models for a "Medical Innovation Prize Fund" developed by CPTech and included in a 2005 bill in the U.S. House of Representatives; and promotion of compensatory liability models as alternatives to exclusive rights to promote downstream innovation).

18. See Sean M. Flynn et al., The U.S. Proposal for an Intellectual Property Chapter for the Trans-Pacific Partnership Agreement, 28 AM. U. INT'L L. REV. 105 (2012) (describing the intellectual property chapter of the currently under negotiation Trans-Pacific Partnership Agreement as a product of a series of "forum shifts" between lawmaking fora); see also Susan K. Sell, TRIPS Was Never Enough: Vertical Forum Shifting, FTAs, ACTA and TPP, 18 J. INTELL. PrOP. L. 447 (2011) (describing a "multi-level" international intellectual property 
foundations—including Rockefeller, MacArthur, and Ford—closed their public interest intellectual property portfolios, creating a funding crisis in the field, IP-intensive industries were going on the offensive with an "enforcement agenda." ${ }^{19}$ Major elements of the enforcement agenda were promoted through an annual Global Congress Combating Counterfeiting and Piracy (“GCCCP”) started in 2004.

Each year the GCCCP assembled more than 500 industry representatives and public officials, resulting in a public "outcomes statement" defining advocacy priorities of a broad network. ${ }^{20}$ The inaugural meeting defined four main objectives:

1. Greater awareness on the full economic and social consequences of counterfeiting among all stakeholders is needed to elevate the issue higher on the political agenda and generate positive action to reduce counterfeiting.

2. Substantially increased cooperation, communication and commitment among the global, regional and national agencies, in partnership with the private sector, are essential in dealing effectively with the counterfeit problem.

3. Steps need to be taken by national, regional and global government bodies to ensure effective introduction and implementation of legislation, with enforcement provisions and penalties that will deter counterfeiting and make it more difficult for organized crime and terrorist groups to benefit financially.

4. More enforcement resources, better trained and more knowledgeable

policymaking arena that has "expanded horizontally, across more multilateral institutions, and it has expanded vertically, from the multilateral level to the most granular”); Laurence R. Helfer, Regime Shifting: The TRIPs Agreement and New Dynamics of International Intellectual Property Lawmaking, 29 YALE J. INT'L L. 1, 6-9 (2004) (describing "regime shifting" strategies of the United States and the European Union to promote a maximalist agenda in the face of resistance in some multilateral fora).

19. See Susan K. Sell, The Global IP Upward Ratchet, Anti-Counterfeiting and Piracy Enforcement Efforts: The State of Play, Am. Univ. WASH. Coll. L. Prog. Info. Justice \& InTELl. Prop. (PIJIP Research Paper Series. No. 15, 2010), available at http://digitalcommons.wcl.american.edu/research/15/.

20. See Congress Archives, GLOBAL CONGRESS, http://www.ccapcongress.net/ archives.htm (collecting links to annual declarations). 
about the issue, need to be devoted to combat counterfeiting. ${ }^{21}$

Most relevant to the global public interest community was the third objective of the GCCCP: the desire to promote "national, regional and global” legislation. Like the Bellagio Dialogues, much of the action in developing concrete proposals to meet the GCCCP's broader agenda occurred outside of the meeting itself. "A Steering Group was established with key partner organizations from the Intergovernmental Organizations and the global business community in order to build the global public-private partnership and to ensure that recommendations were carried through." ${ }^{22}$ And smaller regional meetings were held in key regions to attract local attention and promote specific policy proposals. ${ }^{23}$ By the second convening, the meeting was promoting Japan's proposal for what would later become known as the Anti-Counterfeiting Trade Agreement (ACTA). Drafts of ACTA did not become official until April 2010. ${ }^{24}$

ACTA had begun to draw the attention of the public interest community as early as $2008 .{ }^{25}$ In June 2010, nearly 100 international

21. Outcomes Statement, The First Global Congress ON COMBATING COUNTERFEITING (2004), available at http://www.ccapcongress.net/archives/ Brussels/Files/osfinal.pdf.

22. About the Global Congress, GLOBAL CONGRESS, http://www.ccapcongress.net/about.htm (last visited Nov. 28, 2012); see also Outcomes Statement, supra note 21 (declaring the need to "[i]mmediately establish a Steering Committee, with representation from the key public and private stakeholders, to pursue the recommendations and ideas emanating from the Congress and report formally at a special meeting in Rome, Italy by November 30, 2004”).

23. Regional Events, GLOBAL CONGRESs, http://www.ccapcongress.net/ regional.htm (last visited Nov. 28, 2012) (documenting meetings in Italy, China, Brazil, and Romania).

24. See The Office of the U.S. Trade Representative Releases Draft Text of ACTA, OfFICE OF THE U.S. TRADE REPRESENTATIVE, http://www.ustr.gov/aboutus/press-office/press-releases/2010/april/office-us-trade-representative-releases-

draft-text-a (last visited Nov. 29, 2012); see generally David S. Levine, Transparency Soup: The ACTA Negotiating Process and "Black Box" Lawmaking, 26 AM. U. INT'L L. REV. 811 (2011).

25. The meeting was held June 2-3, 2008, at Open Society Foundations' (“OSF's”) London office, chaired by OSF Information Program Manager Vera Franz. Public organizations began working on the issue earlier in the same year. See 2008 KEI Comments on ACTA Anti-Counterfeiting Treaty, KNOWLEDGE ECOLOGY INT’L (Mar. 20, 2008), http://keionline.org/content/view/169/1; Letter from Canadian Internet Policy and Public Interest Clinic to Foreign Affairs and 
intellectual property scholars and experts from more than a dozen countries gathered on short notice at American University to analyze the version of ACTA officially released just three months earlier. ${ }^{26}$ The meeting was called to create a detailed public "Communiqué," ultimately explaining how the proposed terms of ACTA "threaten numerous public interests, including every concern specifically disclaimed by negotiators." ${ }^{27}$ The meeting was part of a broader

International Trade Canada re: ACTA (Apr. 30, 2008), available at http://www.cippic.ca/sites/default/files/CIPPIC_LT_DFAIT-ACTA-30\%20April\% 2008.pdf.

26. See Public Interest Analysis of the International Intellectual Property Enforcement Agenda, Am. Univ. Wash. Coll. L. Prog. Info. Justice \& INTEll. PROP., http://www.wcl.american.edu/pijip/go/events/june-2010-acta-meeting (last visited Nov. 27, 2012) (linking to a webcast and text of the public Communiqué). Attendees included Tahir Amin, Tatiana Andia, Pat Aufderheide, Tenu Avafia, Brook Baker, Jonathan Band, Susan Bannerman, Denis Borges Barbosa, Heiko Baumaertner, John Bergmayer, Jack Boeve, Annemarie Bridy, Khadijah Britton, Brandon Butler, Michael Carroll, Oona Castro, Alberto Cerda, Maggie Chon, Sai Deepak, Alex Dent, Sarah Deutsch, Kevin Donovan, Rochelle Dreyfuss, Patrick Durisch, Adam Eisgrau, Christine Farley, Alex Feerst, Sean Flynn, Michael Geist, Daniel Gervais, Shuba Ghosh, Robin Gross, Henning Grosse Ruse-Khan, Eldar Haber, David Hammerstein, Cynthia Ho, Bernt Hugenholtz, Meredith Jacob, Peter Jaszi, Asha Jokhoe, Margot Kaminski, Amy Kapczynski, Joe Karaganis, Howard Knopf, Boyan Konstantinov, Gaelle Krikorian, David Levine, James Love, Emi MacLean, Jeremy Malcolm, Rohit Malpani, Peter Maybarduk, Gabriel Michael, John Mitchell, Pedro Mizukami, Emily Mok, Luiz Moncau, Michael Morris, Andrea Murta, Sisule Musungu, Heesob Nam, Tal Niv, Michael Palmedo, Virun Piplani, David Post, Pranesh Prakash, Ana Ramalho, Hafiz Aziz Rehman, Andrew Rens, Martine Courant Rife, Judit Rius Sanjuan, Joshua Sarnoff, Robert Schwartz, Susan Sell, Wendy Seltzer, Xavier Seuba, Johanna Shelton, Sherwin Siy, Sanya Smith, Swarna Soppadandi, Viviana Munoz Tellez, Adam Thomas, Joseph Turcotte, Luis Villarroel, Kim Weatherall, and Chris Wong. For more information on the attendees, see Attendees of June 2010 International IP Enforcement Conference, Am. Univ. WAsh. Coll. L. Prog. Info. Justice \& Intell. Prop., http://www.wcl.american.edu/pijip/go/june2010-attendees (last visited Nov. 27, 2012). Several other meetings in this period were instrumental in pulling together the network that would ultimately be represented at the first Global Congress. These included a meeting on the enforcement agenda organized by the Open Society Institute on June 2-3, 2008, and a meeting of the Trans Atlantic Consumer Dialogue on the released text of ACTA held at the U.S. Department of Commerce on April 28, 2010. More information about the Trans Atlantic Consumer Dialogue is available at http://tacd.org/index.php?option=com_content\&task=view\&id= 159\&Itemid $=1$.

27. Text of Urgent ACTA Communique, Am. Univ. Wash. Coll. L. Prog. Info. Justice \& InTELL. PROP., http://www.wcl.american.edu/pijip/go/actacommunique (last visited Nov. 27, 2012). 
project of American University's Program on Information Justice and Intellectual Property ("PIJIP") to promote scholarship and analysis of the enforcement agenda. The project launched several communication and collaboration tools that were used to promote the meeting and its outcomes, and subsequently used to release public analysis of enforcement-agenda proposals. ${ }^{28}$ These tools included the IP-Enforcement listserv, ${ }^{29}$ the Infojustice.org blog and resource site, ${ }^{30}$ a working paper series, ${ }^{31}$ and an annual published volume of the

28. For public statements that arose from the network and its communications tools, see, e.g., Academics' Letter to President Obama, AM. UnIV. WASH. CoLL. L. Prog. INFo. Justice \& InTEll. Prop. (Oct. 28, 2010), http://www.wcl.american.edu/pijip/go/academics10282010 (arguing that proposed terms in ACTA would be contrary to U.S. law, would threaten public interest concerns, and may violate constitutional requirements for international lawmaking); Submission by 30 Professors to USTR, INFOJUSTICE.ORG (Feb. 15, 2011), http://infojustice.org/wp-content/uploads/2011/02/ACTA-Comment-ThirtyProfessors-USTR-2010-0014.pdf (docket \#ustr-2010-0014) (same); EU Academics Opinion on ACTA Criticized by European Trade Negotiator at EC Stakeholders Meeting, INFOJUSTICE.ORG (Feb. 5, 2011), http://infojustice.org/archives/1097 (linking to an opinion of EU academics on conflicts between ACTA proposals and EU law); Law Professor Letter to Senate Finance Committee, InFOJUSTICE.ORG (May 2012), http://infojustice.org/senatefinance-may2012 (urging the Senate to demand Congressional ratification process for ACTA). See generally PIJIP Research Paper Series on ACTA and the Public Interest, AM. UnIV. WASH. Coll. L. Prog. INFO. Justice \& INTELl. ProP., http://digitalcommons.wcl.american.edu/ research/ (publishing scholarship from 2010 and 2011 analyzing potential public interest impacts of ACTA proposals); Document Search, INFOJUSTICE.ORG, http://infojustice.org/documents-acta-and-access-to-medicine (follow link, then select "Scholarly" tab) (last performed Nov. 27, 2012) (collecting scholarship analyzing ACTA and potential impacts on public interest concerns, particularly access to affordable medicines in developing countries).

29. IP-ENFORCEMENT@ROSTER.WCL.AMERICAN.EDU has 421 subscribers, composed of scholars and experts in international intellectual property law from more than forty countries.

30. INFOJUSTICE.ORG, www.infojustice.org, hosts twenty-four public research libraries and posts news and analysis from thirty-one bloggers from around the world. The site averaged 10,000 monthly unique visitors in the fall of 2012, up from 4,000 in the second half of 2011. Figures compiled by Mike Palmedo, PIJIP Assistant Director for Research, October 2012.

31. PIJIP RESEARCH PAPER SERIES, http://digitalcommons.wcl.american.edu/ research/. In calendar year 2011, the network's working papers received nearly 20,000 downloads and were discussed in more than 100 academic publications or policy reports. Figures compiled by Mike Palmedo, PIJIP Assistant Director for Research, October 2012. See, e.g., DiRECTORATE GENERAL FOR EXTERNAL Policies, European Parliament, The Anti-Counterfeiting Trade 
American University International Law Review. ${ }^{32}$

The Global Congress on Intellectual Property and the Public Interest was a direct outgrowth of the June 2010 meeting on ACTA and the communications tools it created. But the Congress strived to have a different and broader objective. Although the mobilization of the public interest IP community against ACTA was successful in many ways, ${ }^{33}$ it was perceived as having diverted energy from the construction and implementation of a more positive agenda for the field. The Congress was intended to fill that gap, providing a new focal point for the community to recommit to a vision with an explicitly positive outlook.

\section{THE GLOBAL CONGRESS ON INTELLECTUAL PROPERTY AND THE PUBLIC INTEREST}

The initial idea for the Global Congress was hatched at a sidemeeting of representatives of the Centro de Tecnologia e Sociedade Fundação Getulio Vargas Direito Rio (“CTS”), PIJIP, and the International Development Research Centre ("IDRC”) in December $2010 .^{34}$ In early 2011, CTS and PIJIP reached out to some of their partners on research projects funded by IDRC, composing an ad hoc executive committee of Sean Flynn of PIJIP (Chair), Pedro Mizukami of CTS, Joe Karaganis of the American Assembly at Columbia University, and Ahmed Abdel Latif of the International Centre for Trade and Sustainable Development ("ICTSD”). In the lead-up to the Congress, financial funding for participant travel, scholarships for major speakers and representatives from developing countries, and other expenses of the meeting were provided by

AgreEMENT: An AsSESSMENT (2011), available at http://www.europarl.europa.eu/ committees/en/inta/studiesdownload.html?languageDocument=EN\&file=43731 (containing multiple citations to the project's working papers).

32. See, e.g., 26(3) AM. U. INT'L L. REV. and the present issue.

33. The mobilization was instrumental in the ultimate rejection of ratification of the agreement by the EU Parliament, which sapped the momentum for entry into the agreement by other countries.

34. The side-meeting was convened during the Interfaces 10 conference hosted by FGV December 2-3, 2010. Interfaces 10 (Oct. 22, 2010), http://direitorio.fgv.br/cts/interfaces10 (Portuguese). Participants in the sidemeeting included Sean Flynn from PIJIP, Pedro Mizukami of CTS, and Fernando Perini of IDRC. 
IDRC, the Open Society Foundation, Institute for Global and International Studies at George Washington University, Seattle University School of Law, and the Institute for Information Law at the University of Amsterdam. ${ }^{35}$

The inaugural meeting would be held at, and the planning committee chaired by, PIJIP in Washington, D.C. But from the start, it was foreseen that the chair and host of the meeting would rotate, with a second Congress initially planned for Brazil. ${ }^{36}$ One of the purposes of rotating the meeting to different regions each year was to promote a diversity of representation in each. Although each meeting would be global in focus and representation, it was assumed that the time and cost of travel would lead to overrepresentation from whatever region hosted the meeting. ${ }^{37}$

The Congress was planned to combine various elements from previous projects in the field. Like the 1993 Cultural Agency meeting that produced the Bellagio Declaration and the June 2010 meeting at American University on ACTA, the Global Congress set out to convene an interdisciplinary community of scholars and activists to help set an agenda for public interest concerns in the field expressed in a public declaration. More similar to the June 2010 ACTA meeting and the Bellagio Dialogues, the Congress aimed to assemble a large number of representatives from across multiple issue areas to complete its task. The Congress reached a similar number of participants as the Bellagio Dialogues-about 200-but did so in a single time and place rather than over a longer series of meetings. In its mission to be a venue for agenda-setting in a broad community, and in its form of a "Global Congress" hosted by a team of institutions involved in the field, it consciously adopted aspects of

35. Other costs of planning the meeting and support for the maintenance and expansion of the project's communications infrastructure (housed on Infojustice.org) were provided by a grant from IDRC and an unrestricted gift from Google, Inc.

36. The Global Congress has been funded on an annual basis. The planning committee had a five-year vision form the onset but has lacked commitments or a concrete plan to maintain the project for that period as of yet.

37. Cf. Karaganis, supra note 6, at 22 (noting that the proximity of Bellagio to Geneva meant that "Geneva NGOs were able to participate more consistently than other Bellagio partners" and that "continuity was more difficult to maintain among communities separated by greater geographical distance”). 
the GCCCP (and appropriated part of its name).

The ad hoc executive committee met repeatedly via conference calls before the hosting of the Congress to target invitations, review and accept applications from a public call for participation, and outline an agenda and process for drafting a declaration. ${ }^{38}$ The planning ultimately produced a three-part meeting described in the Congress's Concept Note:

The 2011 Congress is intended to help build a "positive agenda" for intellectual property policy in the next decade-one composed of proposals that maximize both technological and cultural innovation and the broader, global public interest. The Congress is intended, first and foremost, to help renew the community needed to think effectively and act collectively on these issues. It will prioritize discussion, networking, and the sharing of resources among roughly 150 academic, practitioner, government and private sector participants from six continents.

- The first half-day (August 25) will be devoted to a series of plenary sessions designed to frame the challenge of building a positive agenda.

- The second day (August 26) will break into two separate tracks of discussion sessions on major themes.

- The third day (August 27) will break further into a series of smaller discussion groups before reconvening for collective discussion of the conference themes and possible collective declarations on key issues. ${ }^{39}$

The Concept Note promoted the hope that "[w]ith luck, this will be the first of a series of annual Congresses to bring together communities of interest on these issues and provide a forum for advancing and coordinating collective projects." ${ }^{40}$ It also described its objective of a concrete outcome in the form of a declaration:

38. The meeting's core documents, including the Washington Declaration on Intellectual Property and the Public Interest, webcasts of the Media Briefing and Opening Plenary, Global Congress Concept Note, Logistical Information for Congress Attendees, Agenda, and the list of participants are available at http://infojustice.org/public-events/global-congress.

39. Global Congress on Intellectual Property \& Public Interest, Concept Note (Aug. 9, 2011), available at http://infojustice.org/wp-content/uploads/2011/03/ Concept-Note-0809820111.pdf.

40. Id. 
It is the hope and expectation of the organizers that Congress participants will help to fashion a general statement on the need for changes in intellectual property law that serve the general public, in contrast to many recent policy proposals that focus only on the interests of enforcing intellectual property rights. On Saturday afternoon, the track chairs will report back thoughts and suggestions for the final conference declaration and open these ideas for general discussion. In the week following the meeting, the track chairs will finalize a draft declaration and post it for additional comment and editing on the Global Congress website. The declaration will be open endorsement after this process.

Endorsement of the declaration will, of course, be optional, and will be open to attendees and non-attendees of the Congress alike. Individuals will not be required to attend the final session in order to endorse the declaration and attendees at the meeting will not be required or assumed to endorse the final text by virtue of their attendance.

The organizers do not expect that every detail of the declaration's language will meet with complete approval from every endorser. We envision a document similar in form to the 1993 Bellagio Declaration, which included this statement:

"Inevitably, each of us would change some word or phrase, or shift some emphasis. Its signatories agree however, to the central themes and spirit of this Declaration and to the urgent sense of concern that motivated it."

The first day of the Congress was devoted to a series of public events and presentations, webcast live and archived. ${ }^{41}$ Although the official agenda started in the afternoon, Congress participants were invited to register for slots in the morning to make public statements in a webcasted forum for dissemination to the press and public. Two such public briefings were held-one released draft reports commissioned by the EU Parliament Green Party on ACTA, and a second highlighted analysis of the Trans-Pacific Partnership's intellectual property and pharmaceutical chapters slated for upcoming negotiations. ${ }^{42}$ In the afternoon, public keynote

41. The opening keynotes and a roundtable discussion on the first day of the Global Congress were held in public and are available for viewing at http://infojustice.org/public-events/global-congress/plenary-webcast.
42. Press
Availability,
August
25, 2011,
INFOJUSTICE.ORG, 
presentations were made on the theme of "tak[ing] stock of recent developments and look[ing] into future challenges pertaining to advancing a 'positive agenda' in international IP law." ${ }^{43}$

The work toward a Congress declaration began on the second day. That day was divided into a series of sessions on discreet topics coordinated in advance by the executive committee to maximize the opportunities for deliberation. The day was filled with ten working sessions on topics broken into two major tracks. One track discussed "Open Access and Limitations \& Exceptions"; the other focused on issues at the intersection of "Enforcement, Trade, and Development." Each track included "a capstone discussion on the 'ways and means' of progressing toward future action and planning." ${ }^{\prime 4}$ During each session within the tracks, several people were identified to lead a discussion with a short presentation, reserving ample time for open discussion of a set of questions posed for all of the session to consider. ${ }^{45}$ The workshops were held under Chatham House Rule to enable open discussion. ${ }^{46}$

http://infojustice.org/public-events/global-congress/press-availability-august-252011.

43. The opening plenary was webcast live and publicly archived. Ahmed Abel Latif, Toward Positive Agendas in International IP Law, INFOJUSTICE.ORG (Aug. 25, 2011), http://infojustice.org/public-events/global-congress/abstracts/towardpositive-agendas-in-international-ip-law.

44. Concept Note, supra note 39.

45. The questions included:

- What should be said about the topic in a general statement on the need for a positive agenda in intellectual property law?

- What research or other further strategic and infrastructure-building work is needed to promote such an agenda?

- What are the essential components of a legal enabling environment to promote important public interests in this area?

- What are likely to be the most hospitable norm-setting institutions for a positive agenda over the next 5 to 10 years?

- How can common problems and possible solutions best be framed?

- Where have positive IP policies been implemented, and what were the

Id. experiences?

46. "When a meeting, or part thereof, is held under the Chatham House Rule, participants are free to use the information received, but neither the identity nor the affiliation of the speaker(s), nor that of any other participant, may be revealed." Chatham House Rule, CHATHAM HouSE, http://www.chathamhouse.org/aboutus/chathamhouserule (last visited Nov. 28, 2012). 
To promote collective drafting of declaration elements, each of the two tracks were assigned a password-protected collaborative notetaking document (in the form of a Google doc) that all of the participants could access and add to. Each session was also assigned an online "document library," where any participant could upload background files to share with Congress participants. The ad hoc executive committee that planned the Congress served as reporters for the main tracks, keeping notes in the open documents for each track with a particular eye for fashioning statements for the final Declaration.

The morning of the third day provided opportunities for the Congress participants to self-organize workshops and meetings. These workshops were proposed by Congress applicants through the application process and chaired by participants. Ultimately, sixteen such self-organized workshops were held at the Congress, with many covering themes that were ultimately noted in the Washington Declaration. ${ }^{47}$

The afternoon of the third day was reserved for a plenary assembly of the Congress to discuss and plan a public declaration. To create a discussion draft, the ad hoc executive committee met before the final plenary to combine contributions from the collaborative notes documents into a single document of declarative language. The rough draft was distributed in hard and electronic copy to all participants before the afternoon session. As described in the concept note quoted above, the intent was never to finalize and adopt a text at the meeting, but rather to provide an opportunity for broad input to guide further work by the executive committee in the weeks following, which would then be recirculated to participants online for further comments before a final release for endorsements.

47. The workshops included sessions covering "ACTA and Beyond," "Methodologies for Studying Digital Media Practices," "Global IP Architecture: Challenges and Strategies for Development," "Open Business Models," "Patent Reform," "Domestic Institutional Innovation," “Amending TRIPS," "Fixing the 1971 Appendix to the Berne Convention," "Development Agenda for Industrialized Countries," "Creative Commons Roundtable," two sessions on "Access to Medicines," and several sessions for miscellaneous presentations of works-in-progress for participant feedback. Global Congress on Intellectual Property and Public Interest, INFOJUSTICE.ORG (Aug. 2011), http://infojustice.org/ public-events/global-congress. 
In a last-minute adjustment to the Congress agenda, the beginning of the Plenary Assembly was divided into small groups to review and propose suggestions for specific sections of the draft declaration. Each small group then reported back their suggestions to the plenary assembly followed by a period of open discussion on each section. The session was ostensibly run under Roberts Rules of Order, although it was in fact facilitated in a more informal manner. ${ }^{48}$ Consensus amendments were inserted directly into the document; those subject to multiple views or framed in less precise wording were tabled for the executive committee to attempt to craft language based on them. On the whole, the plenary Assembly progressed rather smoothly. ${ }^{49}$ Some divisions, particularly in reference to the section on patent policy, emerged in the group, and discussions on that issue in particular continued after the meeting. ${ }^{50}$

After the end of the Congress, the executive committee created a new draft and recirculated it to the Congress's participants through the "Co-ment" text annotation and collaboration tool. ${ }^{51}$ After the close of a short comment period, the committee finalized a draft and released it as the Washington Declaration on Intellectual Property and the Public Interest on September 5, 2011. ${ }^{52}$ The great majority of the Congress's participants endorsed the Washington Declaration soon after its release, and within weeks the document had received nearly 1,000 signatures. ${ }^{53}$ Its text follows.

48. Michael Carroll and Sean Flynn from PIJIP chaired the session, with Michael Carroll primarily in charge of facilitating the public discussion and Sean Flynn recording consensus changes and notes for further reflection in a document broadcast on a large screen for the entire audience to see.

49. The final plenary was attended by less than half of the participants to the Congress, due in large part to the anticipated arrival of Hurricane Irene that day, prompting many to leave early. The reduced numbers likely had the benefit of enabling substantive dialogue with those remaining.

50. Some divisions involved the extent to which the Declaration should endorse policies meant to improve patent "quality," which were seen by some as contrary to more fundamental criticisms of patent policy long supported by many key Congress participants. In the end, these divisions were not successfully mediated in the final text, and some participants refused to endorse the Declaration as a result.

51. See CO-MENT, http://www.co-ment.com (last visited Nov. 28, 2012).

52. Washington Declaration, supra note 1.

53. Id. The signatures for the declaration were lost in a recent website redesign. 
